\title{
PENINGKATAN KUALITAS LAYANAN, KINERJA KARYAWAN DAN \\ KEPUASAN KONSUMEN MELALUI PELATIHAN SOFTSKILL (PROGRAM PENGABDIAN KEPADA MASYARAKAT PADA BKS LPD UBUD)
}

\author{
I W. Suartina, I G. Aryana Mahayasa, \\ Tjok. Istri Tuty I., Ida I D. A. Yayati Wilyadewi \\ Program Studi Manajemen, Fakultas Ekonomi, Universitas Hindu Indonesia
}

\begin{abstract}
The LPD (Village Credit Institution) as an institution that runs the financial functions of traditional and Pakraman villages, is required to have a good performance base, so that it can increase the level of trust and satisfaction of the Pakraman village community as the main consumers of the LPD. One of the efforts to improve LPD performance is by improving the skills and capabilities of human resources that are owned in serving their customers in accordance with the concept of Tri Hita Karana. This community service activity is carried out on LPDs under the management of the BKS LPD Ubud targeting the employees and managers of the LPD. Community service aims to provide an understanding of how basic techniques (soft skills) perform excellent service to customers to improve customer satisfaction, and how to deal with customer complaints and make the complaint a tool to improve service. The method of community service activities is by providing practical skills training provided directly to employees and managers of LPDs under the BKS Ubud, which includes delivery/concept presentations, group discussions, role play/games and case studies. This activity was conducted for one day and was attended by 45 employees and managers of LPDs in the BKS LPD Ubud. The benefits obtained from the results of this training activity are increasing motivation, ability and basic skills of employees facing consumers in accordance with SOP (Standard Operating Procedure) of policy makers and LPD managers, especially those who are members of the Ubud BKS in maintaining quality service to LPD consumers.
\end{abstract}

Keywords: LPD, kepuasan pelanggan, sofskill, pengabdian masyarakat

\section{Pendahuluan}

Salah satu persyaratan penting bagi organisasi untuk bertahan hidup di lingkungan organisasi yang kompetitif saat ini adalah fleksibilitas, kemampuan untuk mengatasi perubahan yang bersifat konstan. Untuk mengembangkan 
kemampuan ini, pendekatan pembelajaran organisasi merupakan satu hal yang mutlak dilakukan, karena belajar adalah sumber utama untuk mengembangkan sikap proaktif dalam menanggapi perubahan, yang pada gilirannya memungkinkan organisasi untuk mengambil posisi superior di pasar (Kim et al., 2017). Telah banyak hasil studi dan penelitian sebelumnya yang menyatakan bahwa pembelajaran organisasi sangat berkorelasi positif dengan isu-isu terkait kinerja individu, kinerja kelompok dalam suatu organisasi, termasuk kinerja organisasi itu sendiri serta loyalitas dan kepuasan karyawan dan konsumen yang berhubungan dengan kinerja organisasi. Pendidikan dan pelatihan berpengaruh positif dan signifikan terhadap kinerja karyawan. Pembelajaran organisasi berpengaruh positif dan signifikan terhadap kinerja (Kunartinah and Sukoco, 2010).

Guna menunjang dan memperlancar pembangunan perekonomian di daerah pedesaan serta untuk meningkatkan kehidupan desa adat, maka dipandang perlu membentuk suatu wadah yang dapat memberikan pinjaman dan menampung segala keperluan masyarakat desa dibidang keuangan, salah satunya dengan keberadaan Lembaga Perkreditan Desa (LPD) yang ditetapkan dengan Peraturan Daerah Propinsi Bali Nomor 8 Tahunn 2002 dan dirubah dengan Perda Propinsi Bali Nomor 3 Tahun 2017 tentang Lembaga Perkreditan Desa. LPD di Bali berbeda dengan LPD yang ada di luar bali, LPD di Bali biasa dikatakan LPD Desa Pakraman. LPD Desa Pakraman bukan hanya sekedar nuansa sosial-ekonomi tetapi juga bercorak kultural-religius. Berkaitan erat dengan pemenuhan dan pelaksanaan kewajiban tidak hanya kewajiban pada alam semesta nyata (skala) tetapi juga kewajiban terhadap alam inmaterial (niskala) krama desa dalam wilayah Desa Pakraman. Lembaga keuangan komunitas desa pakraman bersifat komunal, sosial, ekonomi, dan religius, berbeda dengan orientasi dan filsosofi LPD di daerah lain atau juga lembaga keuangan lainnya (Nurjaya, 2011).

LPD menjalankan fungsi keuangan desa pakraman, yaitu mengelola keuangan desa pakraman, dalam bentuk simpan pinjam, untuk keperluan biaya kehidupan anggota masyarakat desa pakraman, baik secara sendiri-sendiri maupun 
secara bersama-sama, dalam rangka pengembanan fungsi-fungsi sosio-kultural dan keagamaan masyarakat desa pakraman (Mantra, 2005). Sebagai sebuah lembaga yang menjalankan fungsi keuangan desa adat dan desa pakraman, LPD juga dituntut memiliki basis kinerja yang baik sehingga akan dapat meningkatkan tingkat kepercayaan serta kepuasan masyarakat desa pakraman sebagai konsumen utama dari LPD. Beberapa faktor yang dapat mendukung keberhasilan LPD sebagai lembaga perekonomian masyarakat yang berbasis masyarakat hukum adat di Bali yaitu: (a) sinergitas antara sumber daya manusia (SDM) yang dimiliki LPD, yaitu SDM yang memiliki moral yang baik, mental kuat dan mampu memotivasi diri sendiri, dengan konsep Tri Hita Karana yang merupakan dasar filosofis dari berdirinya LPD, keserasian atau keharmonisan antara manusia dengan pencipatnya, yakni Tuhan Yang Maha Esa (parhyangan), manusia dengan alam/lingkungannya (palemahan), dan manusia dengan sesamanya (pawongan) sebagai suatu kesatuan yang utuh (Damayanthi, 2017); (b) kepercayaan masyarakat desa pakraman dengan berbagai produk yang ditawarkan oleh LPD serta kemampuan LPD mengelola kepercayaan masyarakat tersebut; (c) kemampuan LPD menciptakan market leader dan mengatasi para pesaingnya.

Desiyanti et al. (2018) menyatakan bahwa kualitas layanan memiliki pengaruh positif dan signifikan terhadap kepuasan pelanggan, kualitas layanan akan mempengaruhi loyalitas pelanggan melalui mediasi kepuasan pelanggan, serta kepuasan pelanggan berpengaruh positif signifikan terhadap loyalitas pelanggan. Yasa et al., (2017) dalam studinya di LPD Sidakarya menyatakan terdapat 5 faktor yang mempengaruhi kepuasan nasabah terhadap kualitas layanan LPD, yaitu tangibles, reliability, responsiveness, assurance dan empathy yang merupakan persepsi dari pelanggan mengenai layanan yang diberikan sesuai dengan harapan pelanggan. Dengan demikian, kepuasan pelanggan tercapai apabila kualitas layanan yang diberikan baik.

Pengetahuan, keterampilan, dan sikap baik seseorang tidak akan teraktualisasikan dengan baik jika orang tersebut tidak memiliki motivasi/ 
semangat/softskill/daya dorong yang kuat untuk melakukan sesuatu yang diperlukan untuk mencapai tujuan tertentu. Dan jika tujuan tertentu itu adalah searah dengan tujuan (visi dan misi) perusahaan atau orgnaisasi, maka pelatihan softskill memiliki bobot peran yang sangat penting. Softskill sendiri diartikan sebagai kemampuan di luar kemampuan teknis dan akademis, yang lebih mengutamakan kemampuan intra dan interpersonal.

Berdasarkan latar belakang dan fenomena yang dilihat pada tersebut diatas rumusan permasalahan yang ditemukan adalah bagaimana meningkatkan kualitas pelayanan dan kinerja karyawan LPD serta meningkatkan kepuasan konsumen LPD pada wilayah BKS LPD Ubud. Pelatihan ini bertujuan untuk meningkatkan kualitas pelayanan dan kinerja karyawan LPD dan memberikan pelayanan yang prima agar pelanggan mendapatkan kepuasan. Pelatihan ini juga membekali peserta dengan kemampuan secara kepribadian agar dapat menjadi lebih bersahabat dan menyenangkan, sehingga pelanggan dapat merasa nyaman dan menjadi pelanggan loyal serta fanatik. Selain itu, pelatihan ini juga akan membahas bagaimana cara menghadapi komplain pelanggan dan menjadikan komplain tersebut sebuah alat untuk meningkatkan pelayanan.

Pelatihan pelayanan pelanggan penting untuk dilakukan, dan pemberian materi pelatihan pelayanan pelanggan seperti ini penting untuk diberikan, agar karyawan yang bertugas melayani pelanggan dapat lebih memahami tugas yang dijalani. Seorang customer service adalah ujung tombak sebuah perusahaan, yang harus dapat menjembatani antara perusahaan dan juga para klien dengan baik. Mereka harus dapat berkomunikasi dengan baik, dapat mempromosikan produk, memberikan pelayanan yang baik, dan seterusnya. Jika seorang customer service dapat memberikan kepuasan pada para pelanggan tentunya itu akan menjadi kesuksesan juga bagi perusahaan tersebut. Agar dapat menciptakan keberhasilan tersebut tentunya seorang customer service harus diberikan pelatihan yang baik.

Dari pelaksanaan pelatihan ini diharapkan dengan meningkatnya pemahaman karyawan LPD terhadap teknik melakukan pelayanan konsumen yang 
prima maka akan memberikan manfaat kepada semua karyawan LPD untuk selalu belajar memahami pentingnya layanan pelanggan untuk membuat keuntungan dan keberhasilan organisasi, karyawan LPD mampu mengembangkan caracara komunikasi persuasif yang diperlukan untuk memberikan pelayanan pelanggan berkualitas, karyawan LPD mendapatkan nilai-nilai positif dalam membangun reputasi baik perusahaan melalui fungsi dan peran customer service, karyawan LPD mendapatkan motivasi dan inspirasi untuk membangun karakter dan mindset yang bertanggung jawab dalam memberikan pelayanan bermutu tinggi, serta karyawan LPD mendapatkan tips dan trik untuk menuju etos kerja yang

diperkaya dengan nilai-nilai kerja terbaik. Termasuk, dapat mendiskusikan semua persoalan dan tantangan kerja, untuk mendapatkan inspirasi dan motivasi dari pembicara.

\section{Metode Pemecahan Masalah}

Beberapa alternatif pemecahan masalah dapat dilakukan untuk membantu meningkatkan kualitas pelayanan dan kinerja karyawan pada BKS LPD Ubud. Alternatif tersebut diantaranya melakukan studi empiris mengenai faktor-faktor penentu peningkatan kualitas layanan, melakukan penyuluhan serta memberikan pelatihan kepada para karyawan dan pengelola LPD. Dari beberapa alternatif pemecahan masalah tersebut dalam kegiatan pengabdian masyarakat ini, pemberian pelatihan secara langsung kepada karyawan dan pengelola LPD dirasa sebagai cara yang paling efektif untuk memecahkan masalah tersebut. Pelatihan yang dimaksud adalah memberikan pelatihan dasar keterampilan melayani konsumen (softskill).

Metode kegiatan pengabdian masyarakat ini yaitu dengan metode pelatihan keterampilan praktis dalam bentuk pelatihan softskill yang diberikan langsung kepada karyawan dan pengelola LPD pada BKS Ubud, yang meliputi penyampaian/presentasi konsep, diskusi kelompok, latihan/role play/game dan studi kasus. Pelatihan softskill merupakan bentuk pelatihan untuk meningkatkan kemampuan dan keterampilan personal karyawan dalam melakukan pekerjaan dan memberikan pelayanan kepada nasabah. Pelatihan ini dilakukan selama 1 (satu) 
hari, yaitu pada hari Sabtu, tanggal 23 Pebruari 2019 bertempat di aula kantor LPD Silakarang. Peserta pelatihan merupakan karyawan dan pengelola LPD yang berada di bawah naungan badan kerja sama LPD Ubud, dengan jumlah peserta 45 orang.

Materi pelatihan keterampilan dasar (softskill) yang diberikan kepada para karyawan dan pengelola LPD yaitu mencakup:

1. Prinsip dasar memberi pelayanan prima:

a) Bisnis dan persaingan dalam industri pelayanan jasa

b) Pelayanan menjadi senjata utama persaingan bisnis

c) Prinsip dasar pelayanan prima

2. Sikap, perilaku dan penampilan dalam melayani
a) Sikap dan perilaku yang diperlukan untuk memberikan pelayanan
b) Sikap dan perilaku kerja yang profesional
c) Penampilan yang pantas dalam melayani

3. Pengenalan Customer Service
a) Pengertian Customer Service
b) "Moment of the Truth" Customer Service
c) Dampak pelayanan internal dan eksternal
d) Bagaimana memberikan pelayanan konsumen
e) Komunikasi empathi dalam melayani
f) Komunikasi assertif dalam melayani

4. Teknik Menangani Keberatan dan Keluhan

a) Kenapa konsumen tidak puas

b) Sikap yang sesuai untuk menghadapi keberatan dan keluhan

c) Strategi umum menangani keberatan dan keluhan

d) Menentukan keberatan dan keluhan yang tersembunyi

e) Metode dasar untuk penanganan keberatan dan keluhan

f) Tipe-tipe keberatan dan keluhan

Kegiatan pengabdian kepada masyarakat ini dibuka secara langsung oleh Bapak Ketua Program Studi Manajemen Fakultas Ekonomi UNHI, Bapak I Wayan 
Suartina. Pembukaan kegiatan ini juga didampingi oleh Bapak I Wayan Karma, SE., selaku Ketua Badan Kerja Sama LPD Ubud. Maksud dan sasaran yang ingin dicapai dari kegiatan pelatihan ini juga sekalian disampaikan oleh Bapak Kaprodi Manajemen FE UNHI.

Sebelum dimulainya pelatihan, semua peserta diberikan tes awal untuk mengetahui kondisi awal yang dimiliki peserta terhadap pemahaman mereka mengenai softskill dan dasar-dasar pelayanan prima. Setelah diberikan materi pelatihan dan beberapa latihan maupun praktek game serta studi kasus, kegiatan diakhiri dengan kembali memberikan tes evaluasi hasil pelatihan untuk mengetahui seberapa jauh peserta memahami materi pelatihan yang sudah diikuti.

Materi prinsip dasar memberi pelayanan prima dan sikap, perilaku dan penampilan dalam melayani diberikan langsung oleh bapak Kaprodi, Bapak I Wayan Suartina. Sedangkan materi mengenai pengenalan customer service dan teknik menangani keberatan dan keluhan nasabah diberikan oleh I Gede Aryana Mahayasa, yang dilanjutkan dengan latihan praktek berdasarkan studi kasus yang diberikan.

\section{Hasil dan Pembahasan}

Penyelenggaraan kegiatan pelatihan softskill kepada karyawan dan pengelola LPD di bawah Badan Kerja Sama LPD Ubud menggunakan metode ceramah, dan beberapa studi kasus serta game terkait dengan pelayanan prima terhadap nasabah LPD. Materi kegiatan serta alat yang diperlukan disediakan oleh Program Studi Manajemen FE UNHI, sedangkan perlengkapan penunjang kegiatan di tempat pelatihan, seperti meja, kursi, pengeras suara mendapat dukungan dari LPD Silakarang sebagai tempat berlangsungnya kegiatan. Kegiatan pengabdian dilaksanakan selama satu hari yaitu pada hari Sabtu, 23 Pebruari 2019.

Adapun hasil kegiatan pengabdian yang dilaksanakan pada Sabtu, 30 Juni 2018 adalah sebagai berikut:

1. Kegiatan diawali dengan registrasi peserta. 
2. Berikutnya dilakukan kegiatan persiapan pembukaan kegiatan pengabdian kepada masyarakat dalam bentuk pelatihan softskill. Pelatihan softskill ini diikuti oleh 45 orang peserta yang merupakan perwakilan dari beberapa karyawan dan pengelola LPD yang berada di bawah naungan BKS LPD Ubud.

3. Pembukaan kegiatan pengabdian kepada masyarakat dilakukan oleh Bapak Kaprodi Manajemen FE UNHI yang didampingi oleh Bapak Ketua BKS LPD Ubud dan beberapa staf yang hadir pada kegiatan tersebut.

4. Setelah upacara pembukaan dilakukan, dilanjutkan dengan pemberian tes awal (pre-test) kepada semua peserta kegiatan. Tujuan diberikannya pre-test ini adalah untuk mengetahui kemampuan pemahaman awal peserta mengenai kegiatan pelatihan softskill yang akan mereka ikuti.

5. Kegiatan dilanjutkan dengan penyajian materi terkait dengan prinsip dasar memberi pelayanan prima dan sikap, perilaku dan penampilan dalam melayani, yang disampaikan langsung oleh bapak Kaprodi Manajemen FE UNHI. Selama penyajian materi juga dilakukan tanya jawab serta meminta tanggapan dari peserta mengenai kegiatan-kegiatan yang selama ini telah dilakukan dalam melayani nasabah. Para peserta juga diajak untuk sharing pengalamannya dalam bekerja. Kemudian pemateri memberikan masukan bagaimana seharusnya sikap dalam melayani konsumen atau nasabah LPD.

6. Kegiatan pemberian materi kemudian dilanjutkan dengan materi mengenai pengenalan customer service dan teknik menangani keberatan dan keluhan nasabah diberikan oleh I Gede Aryana Mahayasa. Pada sesi ini juga hampir sama dengan sesi sebelumnya, selain ceramah pemaparan materi, peserta juga diajak berdiskusi dan diminta pendapat dan pengalamannya selama bekerja melayani konsumen.

7. Setelah pemaparan materi yang berlangsung kurang lebih tiga jam, kegiatan dilanjutkan dengan melakukan simulasi game. Pemateri memberikan beberapa contoh kasus dan beberapa masalah yang sering dihadapi LPD serta keluhankeluhan yang sering disampaikan oleh konsumen/nasabah LPD. Peserta dibagi 
menjadi beberapa kelompok diminta untuk mencari solusi dari setiap kasus yang diberikan. Pada simulasi praktek, peserta juga diminta untuk mempraktekkan kegiatan mereka ketika berhadapan dengan konsumen dan praktek menangani keluhan yang disampaikan oleh konsumen. Dalam kegiatan praktek ini peserta juga dibagi, ada yang berperan sebagai nasabah dan yang lainnya sebagai customer service LPD.

8. Setelah kegiatan ceramah dan simulasi game selesai, kegiatan kemudian dilanjutkan dengan pemberian tes akhir (post-test) untuk mengetahui seberapa baik pemahaman dan penangkapan peserta terhadap materi-materi yang telah diberikan selama kegiatan pelatihan tersebut.

9. Kegiatan diakhiri dengan acara penutupan yang dilakukan oleh Bapak Ketua BKS LPD yang dilanjutkan dengan kegiatan ramah tamah.

Dari rangkaian kegiatan pelatihan selama satu hari tersebut, terdapat beberapa hal yang bisa digambarkan, yaitu:

a. Mengenai kondisi karyawan dan pengelola LPD secara umum di bawah BKS LPD Ubud.

BKS LPD Ubud yang membawahi kurang lebih 30 LPD yang berada di wilayah kecamatan Ubud memiliki karyawan dan pengelola yang berasal dari latar belakang pendidikan, pengalaman dan keterampilan yang berbeda-beda. Sebagian besar pendekatan yang selama ini dilakukan ketika menghadapi nasabah atau konsumen LPD yang merupakan warga desa di lingkungan setempat dengan menggunakan pendekatan kekeluargaan dan informal. Karyawan dan pengelola LPD masih perlu lebih memahami pentingnya keberadaan nasabah untuk perkembangan dan pertumbuhan LPD. Mereka juga jarang mendapatkan kesempatan untuk bertemu satu dengan yang lainnya untuk saling membagi pengalaman dan informasi.

b. Antusiasme peserta dalam mengikuti pelatihan softskill

Selama mengikuti kegiatan pelatihan sehari ini terlihat semua peserta sangat antusias. Peserta seperti memperolah suasana yang berbeda ketika mengikuti 
kegiatan tersebut. Dan dari diskusi serta tanya jawab yang dilakukan selama pelatihan, cukup banyak sebenarnya permasalahan yang mereka hadapi selama melayani konsumen. Mulai dari kesulitan berkomunikasi, rendahnya kesadaran warga desa untuk memanfaatkan fasilitas pelayanan dan produk yang ditawarkan LPD, kesulitan proses pemasaran produk LPD, kemampuan memberikan pelayanan yang baik kepada konsumen/nasabah. Tapi ada juga beberapa peserta yang beranggapan, bahwa mereka selama ini sudah berusaha memberikan pelayanan prima, tapi karena watak sebagian warga desa, selalu merasa kurang puas terhadap pelayanan yang diberikan.

c. Terkait pelaksanaan simulasi dan praktek game

Ketika kegiatan simulasi dilakukan, kami bisa melihat secara tidak langsung apa yang selama ini telah dilakukan oleh peserta dalam melayani konsumen serta menanggapi keluhan-keluhan konsumen. Karena kurangnya keterampilan dan keseragaman cara penanganan keluhan konsumen, terlihat mereka seolah-oleh memiliki caranya masing-masing. Dan mereka juga mengklaim bahwa cara yang mereka lakukan bisa menyelesaikan masalah yang dihadapi. Dari kegiatan ini kami juga memberikan masukan kepada Ketua BKS untuk memberikan masukan kepada para pengelola LPD untuk membuat SOP (aturan operasi standar) setiap kegiatan yang dilakukan di lingkungan LPD. Sehingga ada keseragaman dan standar yang jelas ketika memberikan pelayanan yang prima kepada konsumen.

d. Harapan BKS LPD Ubud

Dari kegiatan tersebut, Ketua BKS LPD Ubud juga mengutarakan harapannya supaya kegiatan pelatihan seperti ini tidak hanya berlangsung sekali saja. Tapi dilakukan berkelanjutan dan juga diberikan pelatihan-pelatihan yang lainnya, seperti pelatihan dasar kepemimpinan, pelatihan team buiding, dan pelatihan penguasaan teknologi informasi. Kami dari program studi manajemen menyambut baik apa yang menjadi harapan BKS LPD Ubud tersebut. Dengan sudah terbentuknya kerja sama antara FE UNHI dan BKS LPD Ubud kami juga 
akan berusaha untuk selalu datang dan hadir ke sana memberikan pelatihan, penyuluhan maupun kegiatan-kegiatan yang dapat meningkatkan kinerja LPD secara umum.

\section{Penutup}

\section{Simpulan dan Saran}

Berdasarkan hasil kegiatan pengabdian kepada masyarakat yang dilakukan Program Studi Manajemen FE UNHI melalui kegiatan pelatihan softskill, dapat disimpulkan bahwa dilakukannya kegiatan pelatihan softskill ini dapat meningkatkan pemahaman dan kesadaran karyawan dan pengelola mengenai pentingnya dasar-dasar pelayanan yang prima kepada konsumen. Peningkatan pelayanan kepada konsumen dan nasabah LPD akan dapat meningkatan kualitas pelayanan dan kinerja karyawan serta organisasi LPD secara umum. Penyampaian materi mengenai prinsip dasar memberi pelayanan prima dan sikap, perilaku dan penampilan karyawan dalam melayani konsumen akan dapat meningkatkan kesadaran karyawan dalam bersikap dan berperilaku dihadapan konsumen.

Selain itu, materi mengenai pengenalan customer service dan teknik menangani keberatan dan keluhan nasabah akan meningkatkan kemampuan dan keterampilan karyawan sebagai pemberi solusi setiap permasalahan nasabah. Pada akhirnya kepuasan nasabah terhadap pelayanan yang diberikan oleh LPD akan meningkat. Kegiatan simulasi dan game juga sangat tepat digunakan untuk meningkatkan keakraban, kerjasama dan pemahaman cara menjadi seorang customer service yang baik dan peningkatan kemampuan memberikan pelayanan yang baik.

Dari kegiatan pengabdian kepada masyarakat yang telah dilakukan, terdapat beberapa saran yaitu: 
1. LPD dibawah badan kerja sama diharapkan selalu memberikan kesempatan kepada karyawan dan pengelolanya untuk meningkatkan dan mengembangkan kemampuan personal karyawan dan pengelolanya dalam rangka peningkatan kinerja LPD.

2. Perlu dilakukan kegiatan-kegiatan pelatihan sejenis secara berkala yang bertujuan untuk meningkatkan pengetahuan dan keterampilan karyawan dan pengelola LPD mengenai tugas dan tanggung jawabnya masing-masing.

3. Kerja sama antara Program Studi Manajemen FE UNHI dan BKS LPD Ubud yang sudah berjalan sampai sekarang ini supaya terus dipertahankan, bahkan ditingkatkan lagi di masa yang akan datang.

\section{Ucapan Terima Kasih}

Kegiatan pengabdian kepada masyarakat melalui kegiatan pelatihan softskill selama satu hari ini berlangsung dengan lancar dikarenakan dukungan dari beberapa pihak. Penulis sekaligus pelaksana kegiatan pengabdian ini mengucapkan ucapan terimakasih sebesar-besarnya kepada lembaga Universitas Hindu Indonesia melalui LPPM UNHI atas hibah dana pembiayaan kegiatan pengabdian ini, jajaran pimpinan Fakultas Ekonomi UNHI atas dukungan moral dan persetujuan kegiatan ini, serta jajaran pimpinan, pengelola dan karyawan LPD di bawah badan kerjasama LPD UBUD yang sudah memberikan kesempatan dan juga mendukung penyediaan tempat serta sarana yang digunakan selama kegiatan pelatihan berlangsung dan mengikuti kegiatan pelatihan ini sampai akhir.

\section{Daftar Pustaka}

Damayanthi, I.G.A.E., 2017. Pengungkapan Tanggung Jawab Sosial Lembaga Perkreditan Desa (LPD) Berdasarkan Filosofi Tri Hita Karana. OJS.Unud. Universitas Udayana.

Desiyanti, N.L., Sudja, I.N., Martini, L.K.B., 2018. Effect of Service Quality on Customer Satisfaction, Customer Delight and Customer Loyalty (Study on 
LPD Desa Adat Sembung and LPD Desa Adat Seseh). International Journal of Contemporary Reasearch and Review Vol. 09, 20660-20668.

Kim, K., Watkins, E.K., Lu, Z., 2017. The Impact of a Learning Organization on Performance: focusing on Knowledge Performance and Financial Performance. European Journal of Training and Development Vol. 41, 132.

Kunartinah, Sukoco, F., 2010. Pengaruh Pendidikan dan Pelatihan, Pembelajaran Organisasi terhadap Kinerja dengan Kompetensi sebagai Mediasi. Jurnal Bisnis dan Ekonomi (JBE) Vol. 17, Pg. 74 - 84.

Mantra, I.B., 2005. Sejarah dan Perkembangan Lembaga Perkreditan Desa di Bali. Setda Pemprov Bali, Denpasar.

Nurjaya, I.N., 2011. Landasan Teoritik Pengaturan LPD. Udayana University Press, Denpasar.

Yasa, I.P.A., Suciptawati, N.L.P., Susilawati, M., 2017. Implementasi Analisis Faktor dalam Menganalisis Kepuasan Nasabah terhadap Kualitas Layanan (Studi Kasus: LPD Sidakarya). E-Jurnal Matematika Vol. 6, 152-160. 